\title{
Aplikasi Manajemen Keuangan Berbasis Web Dinas Komunikasi dan Informatika Kabupaten Tanah Laut
}

\author{
Agustian Noor $^{1)}$, Syaiful Hadi ${ }^{2)}$ \\ 1)2) Jurusan Teknik Informatika, Politeknik Negeri Tanah Laut \\ Jl. A. Yani Km 6 Pelaihari Tanah Laut Kalimantan Selatan \\ Telepon: (0512) 2021065 \\ 1) agustiannoor@ymail.com \\ 2) syaifulhadi171022@gmail.com
}

\begin{abstract}
Abstrak
Bidang Keuangan Diskominfo mempunyai kegiatan antara Lain kegiatan anggaran dana belanja, kegiatan Dpa dan cetak kwitansi dan proses manajemen keuangan pada diskominfo melakukan pengelolaaan anggaran dana untuk setiap kegiatan dan melakukan perekapan data anggaran, dalam proses pencairan dana kegiatan masih saja sulit untuk di lakukan karena dalam proses Input data dan cetak data masih saja di lakukan dengan cara konvensional. Pegawai datang kepada admin untuk meminta pembuatan kwitansi keuangan belanja kegiatan DPA, admin membuat kwitansi yang di minta pegawai dengan menginputkan data data yang di inginkan berupa kegiatan DPA, program DPA, Nama penerima dan Dana kegiatan. Kemudian admin menyerahkan kwitansi yang sudah di buat kepada verifikator untuk memverifikasi bahwa data anggaran dan data kegiatan benar. Apabila data sudah di cek oleh verifikator dan data di nyatakan valid maka kwitansi diserahkan kepada bendahara untuk proses pencairan data anggran kegiatan DPA. Permasalahan tersebut dapat diselesaikan dengan suatu aplikasi yang mempermudah dalam pekerjaan di bidang keuangan. Aplikasi Manajemen Keuangan yang telah dibangun dan sudah terkomputerisasi dapat mempermudah bagian keuangan untuk memanajemen data keuangan secara lebih efektif dan efisien. Dibangunnya sistem ini dapat membantu bagian keuangan dalam Pembuatan kwitansi keuangan pada dinas komunikasi dan informatika Tanah Laut.
\end{abstract}

Kata kunci: Aplikasi, Keuangan, Database, MySQL, PHP

\begin{abstract}
The financial area of Diskominfo has activities such as spending budget activities, DPA activities and printing receipts and financial management processes on the Diskominfo to conduct budget funds for each activity and to conduct data Budget, in the process of disbursement of activities is still difficult to do because in the process of data Input and print data is still done in a conventional way. Employees come to the admin to ask for the creation of financial receipts for DPA activities, the admin makes a receipt that is asked by the employee by inputting data data in the form of DPA activities, DPA programs, recipient name and activity funds. Then admins submit a receipt that has been made to the verifier to verify that the budget data and activity data are correct.If the data has been checked by the Verificator and the data stated is valid then the receipt is left to the treasurer for the process of disbursement of data on DPA activities. These problems can be solved with an application that facilitates the work in the field of finance.The built-in and computerized financial management applications make it easier for the financial part to manage financial data more effectively and efficiently. Construction of this system can help the financial part in making financial receipts to the Communications and Informatics Service of Tanah Laut.
\end{abstract}

Keywords: Application, Financial, Database, MySQL, PHP 


\section{PENDAHULUAN}

Dinas Komunikasi Dan Informatika (Diskominfo) Kabupaten Tanah Laut adalah sebuah Instansi pemerintahan yang berdomisili di Pelaihari. Diskominfo mempunyai beberapa bidang yaitu bidang komunikasi, bidang penyelenggaraan e-government, bidang keuangan serta bidang statistik dan persandian.

Bidang Keuangan Diskominfo mempunyai kegiatan antara lain kegiatan anggaran dana belanja, kegiatan DPA, cetak kwitansi, mengatur keuangan pada Diskominfo, melakukan pengelolaaan anggaran dana untuk setiap kegiatan dan melakukan perekapan data anggaran. Proses pencairan dana kegiatan sulit dilakukan karena proses input dan cetak data masih dilakukan dengan menggunakan aplikasi Microsoft Excel yang kemudian disalin ke Microsoft Word sehingga membentuk suatu kwitansi yang kemudian disimpan dalam format PDF. Hal ini membuat proses pengerjaan menjadi lambat dan tidak efisien.

Permasalahan tersebut dapat diselesaikan dengan suatu aplikasi yang mempermudah dalam pekerjaan di bidang keuangan. Dengan adanya Aplikasi Manajemen Keuangan yang sudah terkomputerisasi dapat mempermudah bagian keuangan untuk memanajemen data keuangan secara lebih efektif dan efisien, mempermudah pembuatan kwitansi belanja kegiatan DPA, dan mempermudah pencarian data yang berjumlah banyak dengan cara yang cepat. Aplikasi ini dibuat menggunakan bahasa pemrograman PHP dan MySQL sebagai databasenya.

\section{TINJAUAN PUSTAKA}

\subsection{Aplikasi}

Aplikasi adalah program komputer yang terasosiasi dengan dokumentasi perangkat lunak seperti dokumentasi kebutuhan, model desain, dan cara penggunaan (Sukamto \& Shalahuddin, 2016). Aplikasi adalah program komputer atau perangkat lunak yang didesain untuk mengerjakan tugas tertentu (Kementerian Pendidikan dan Kebudayaan Republik Indonesia, 2016).

Aplikasi diadopsi dari Bahasa Inggris "Application" yang berarti penggunaan atau penerapan. Pengertian aplikasi secara lengkap adalah suatu penerapan perangkat lunak (software) yang dikembangkan untuk melakukan tugas tertentu (Syafitri, 2019). Berdasarkan pengertian tersebut, dapat disimpulkan aplikasi adalah program komputer yang diterapkan (diaplikasikan) untuk mengelola data menjadi informasi guna membantu pekerjaan manusia.

\subsection{Keuangan}

Keuangan merupakan ilmu dan seni dalam mengelola uang yang mempengaruhi kehidupan setiap orang dan setiap organisasi. Keuangan berhubungan dengan proses, lembaga, pasar, dan instrumen yang terlibat dalam transfer uang diantara individu maupun antara bisnis dan pemerintah (Sundjaja \& Berlian, 2003).

\subsection{Database}

Database adalah sistem terkomputerisasi yang tujuan utamanya adalah memelihara data yang sudah diolah atau informasi dan membuat informasi tersedia saat dibutuhkan. Pada intinya database adalah media untuk menyimpan data agar dapat diakses dengan mudah dan cepat (Sukamto \& Shalahuddin, 2016). Database menyimpan data yang jenisnya beraneka ragam. Keuntungan menyimpan data di database adalah kemudahanya dalam penyimpanan dan menampilkan data karena dalam bentuk tabel (Winarno, Zaki, \& SmitDev Community, 2014).

\subsection{My Structure Query Language (MySQL)}

MySQL tergolong Database Management Sytem (DBMS). Perangkat ini bermanfaat untuk mengelola data dengan cara yang sangat fleksibel dan cepat. MySQL banyak dipakai untuk kepentingan penanganan database karena selain handal juga bersifat open source (Kadir, 2010).

MySQL adalah database yang termasuk jenis Relational Database Management System (RDBMS). Itulah sebabnya istilah seperti tabel, baris, dan kolom digunakan pada MySQL (Wahana Komputer, 2014). 


\subsection{Perl Hypertext Preprocessor (PHP)}

Perl Hypertext Preprocessor (PHP) adalah bahasa server-side yang menyatu dengan HTML untuk membuat halaman web yang dinamis. Karena PHP merupakan serverside-scripting maka sintaks dan perintah-perintah PHP akan dieksekusi di server kemudian hasilnya akan dikirmkan ke browser dengan format HTML (Isa \& Hartawan, 2017).

PHP merupakan bahasa berbentuk script yang ditempatkan di dalam server baru kemudian diproses. Hasil pemrosesan dikirimkan kepada web browser klien. Bahasa pemrograman PHP ini dirancang khusus untuk membentuk web dinamis (Wahana Komputer, 2014).

\section{METODE PENELITIAN}

\subsection{Metode Wawancara}

Wawancara adalah kegiatan yang paling tepat antara sistem analis dengan organisasi atau perusahaan dan merupakan teknik yang produktif dalam mencari informasi. Hal ini dikarenakan dalam wawancara pencari dan pemberi data dapat langsung bertukar pikiran. Pada metode ini, penulis melakukan wawancara dengan Kepala Bidang Penyelenggaraan E-Government yaitu Bapak Zaki dan dengan bagian Keuangan yaitu Bapak Fauzi. Penulis menanyakan beberapa informasi mengenai manajemen keuangan yang ada di Diskominfo Kabupaten Tanah Laut.

\subsection{Metode Pustaka}

Dalam metode pustaka, penulis mendapatkan beberapa data Keuangan dari Bagian Admin dan Bendahara Keuangan Dinas Komunikasi dan Informatika Kabupaten Tanah Laut.

\section{PEMBAHASAN}

\subsection{Analisis Sistem yang Berjalan}

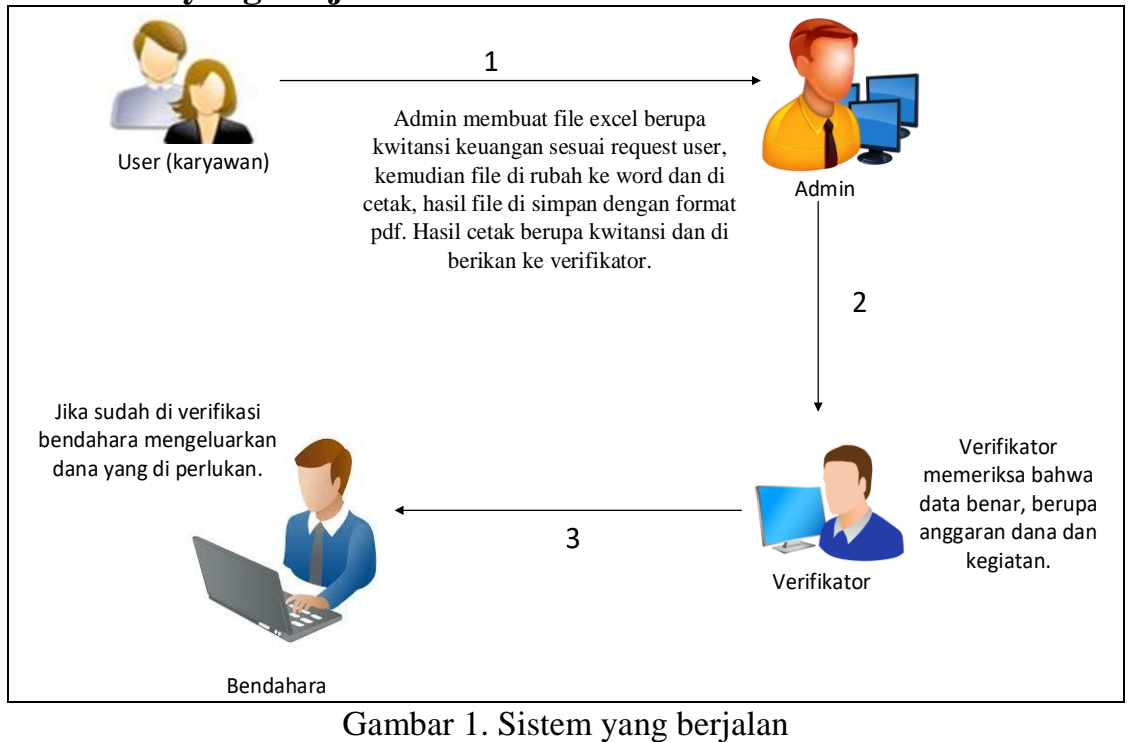

Gambar 1 adalah sistem yang sedang berjalan menurut kasus, dijelaskan sebagai berikut:

1. User datang kepada admin lalu meminta pembuatan kwitansi belanja kegiatan DPA.

2. Admin membuatkan kwitansi dengan kegiatan DPA yang diinginkan oleh user, kemudian kwitansi diberikan kepada verifikator untuk diverifikasi apakah data kegiatan dan anggaran dana kegiatan sudah benar.

3. Verifikator melakukan cek kepada kwitansi apakah data kegiatan DPA dan anggaran dana sudah benar, kemudian verifikator memberikan kwitansi kepada bendahara untuk proses pencairan dana kegiatan DPA.

4. Bendahara melakukan pencairan dana kegiatan DPA. 


\subsection{Analisis Sistem yang Diusulkan}

Analisis sistem yang diusulkan dapat dilihat pada Gambar 2.

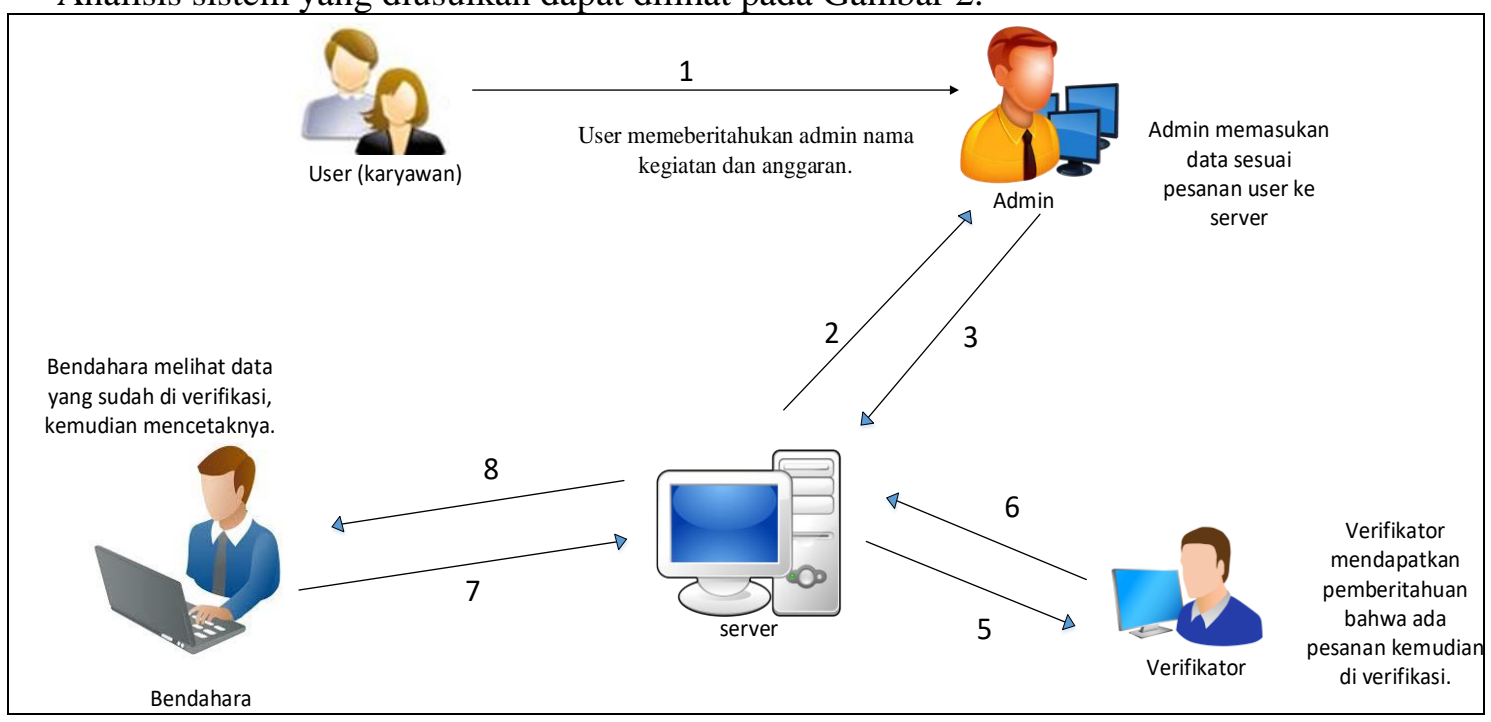

Gambar 2. Sistem yang diusulkan

Gambar 2 adalah sistem yang diusulkan oleh penulis, dijelaskan sebagai berikut.

1. User memberikan informasi pembuatan kwitansi belanja kegiatan DPA

2. Admin menginputkan di aplikasi.

3. Verifikator memeriksa kwitansi pada aplikasi.

4. Bendahara melihat data sudah diverifikasi dan mencairkan dana kegiatan DPA.

\subsection{Entity Relationship Diagram (ERD)}

Berikut adalah rancangan ERD pada Aplikasi Manajemen Keuangan Berbasis Web Dinas Komunikasi dan Informatika Kabupaten Tanah Laut, dapat dilihat pada Gambar 3.

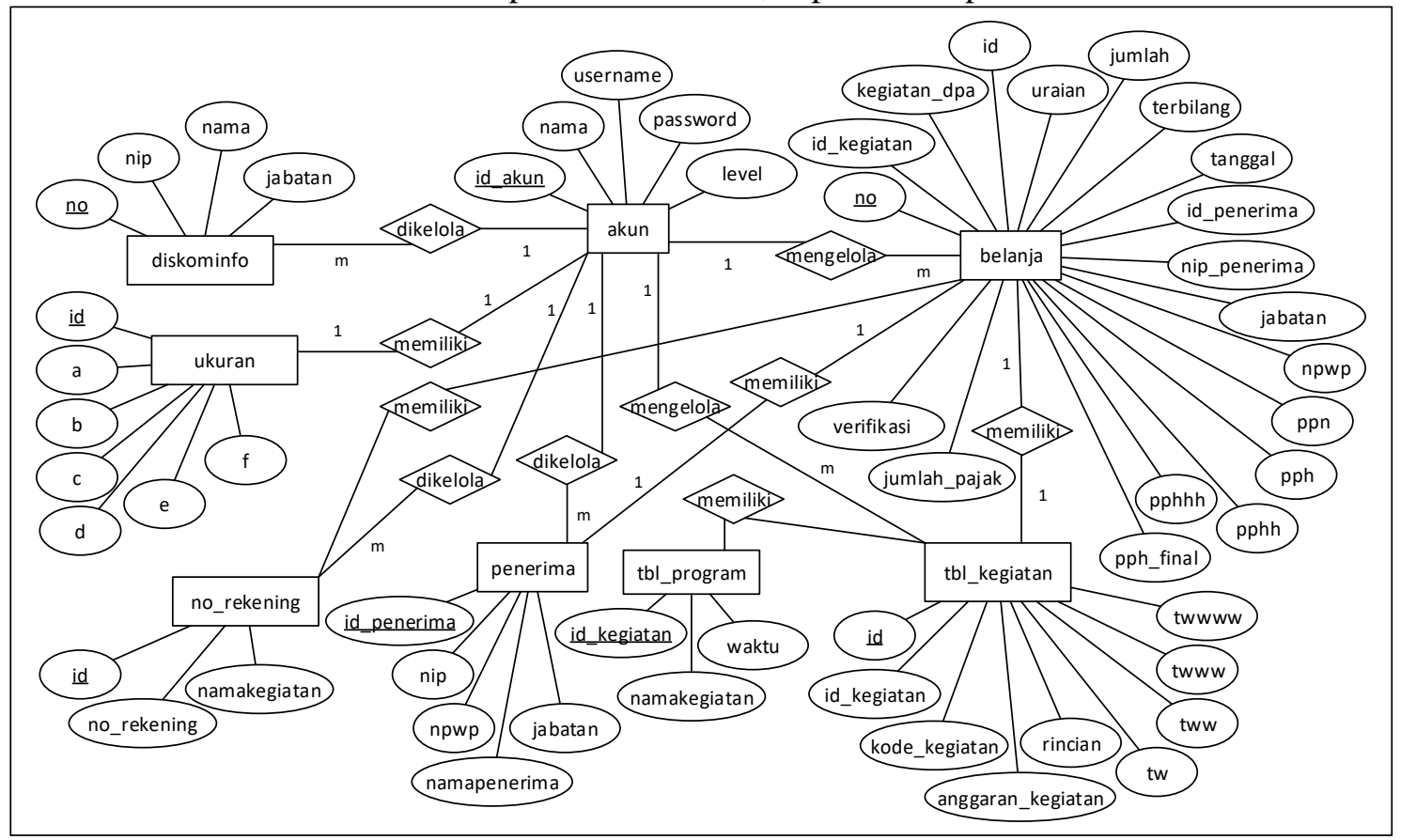

Gambar 3. ERD

Gambar 3 adalah alur database yang terdiri atas delapan entitas, setiap entitas mewakili nama tabel yang ada di database Aplikasi Manajemen Keuangan Berbasis Web Dinas Komunikasi dan 
Informatika Kabupaten Tanah Laut. Setiap atribut yang ada mewakili kolom-kolom yang ada pada database. Relasi yang menghubungkan entitas-entitas sesuai peranannya, bobot peranan entitas dapat dilihat pada kardinalitasnya.

\subsection{Data Flow Diagram (DFD) Konteks}

Berikut adalah rancangan sistem DFD Konteks pada Aplikasi Manajemen Keuangan Berbasis Web Dinas Komunikasi dan Informatika Kabupaten Tanah Laut, dapat dilihat pada Gambar 4.

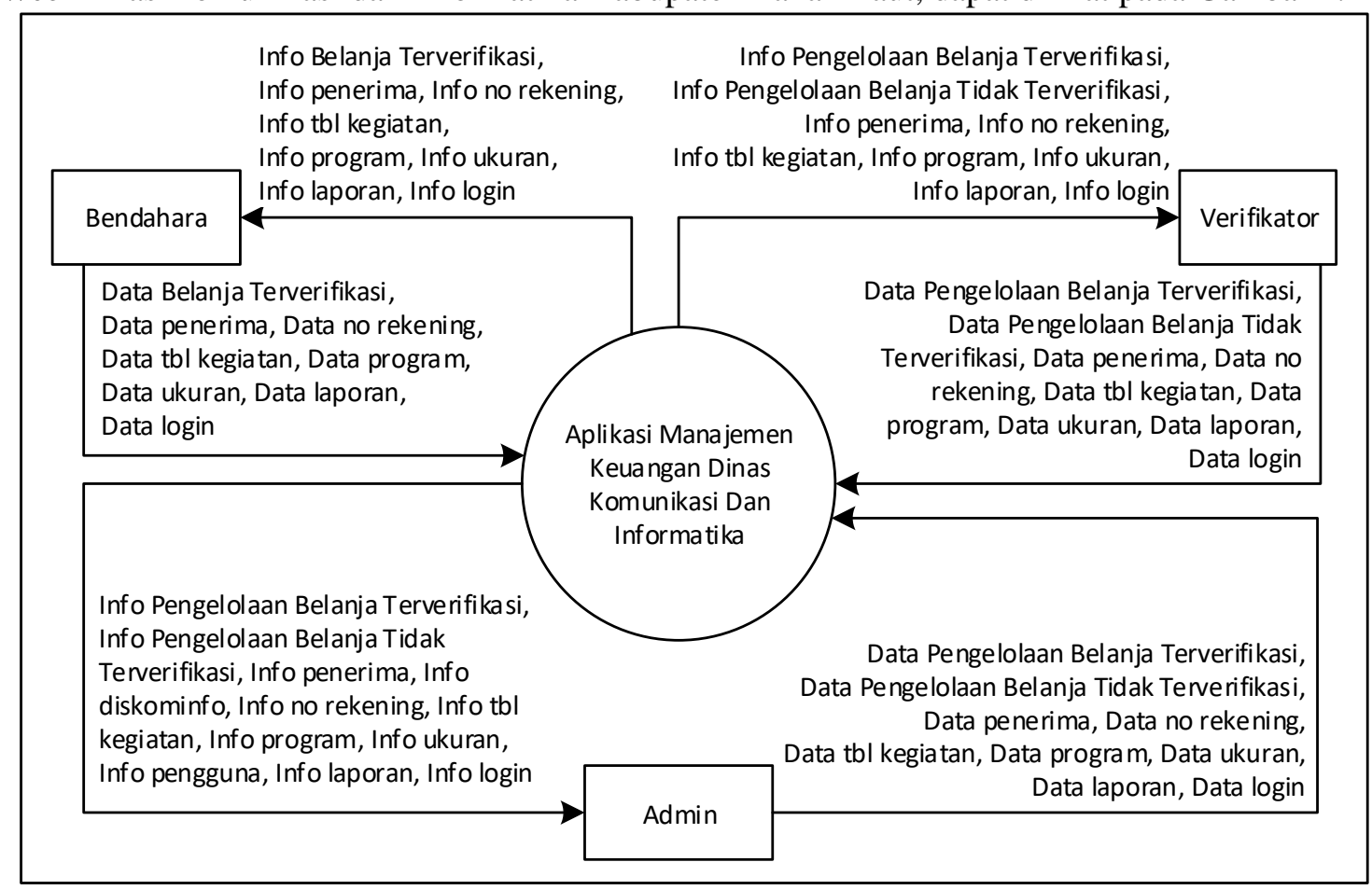

Gambar 4. DFD Konteks

Gambar 4 mendeskripsikan diagram konteks yang terdapat 3 pengguna yang memiliki hak akses, yaitu Admin, verifikator dan bendahara (HR dan SHE). Admin dapat memasukkan data login, data belanja, data diskominfo, tambah data, data persetujuan, data penerima, data arsip, data no rekening, data kegiatan DPA, data akun. Verifikator dapat memasukkan data login, data terverifikasi, data belum terverifikasi, Tambah data, data penerima, data no rekening dan data kegiatan DPA. Bendahara dapat memasukkan data login, data terverifikasi, Tambah data, data penerima, data no rekening dan data kegiatan DPA. Admin mendapatkan info login, info belanja, info tambah data, info Diskominfo, info penerima, info arsip, info no rekening, info kegiatan DPA, info akun. Verifikasi mendapatkan info login, info data belum terverifikasi, info data terverifikasi, info tambah data, info info penerima, info no rekening, info kegiatan DPA dan info akun. Bendahara mendapatkan info login, info data terverifikasi, info tambah data, info info penerima, info no rekening, info kegiatan DPA dan info akun.

\subsection{Implementasi Aplikasi}

Berikut adalah implementasi dari Aplikasi Aplikasi Manajemen Keuangan Berbasis Web Dinas Komunikasi dan Informatika Kabupaten Tanah Laut, dapat dilihat pada Gambar 5 sampai dengan Gambar 11. 


\subsubsection{Antarmuka Login}

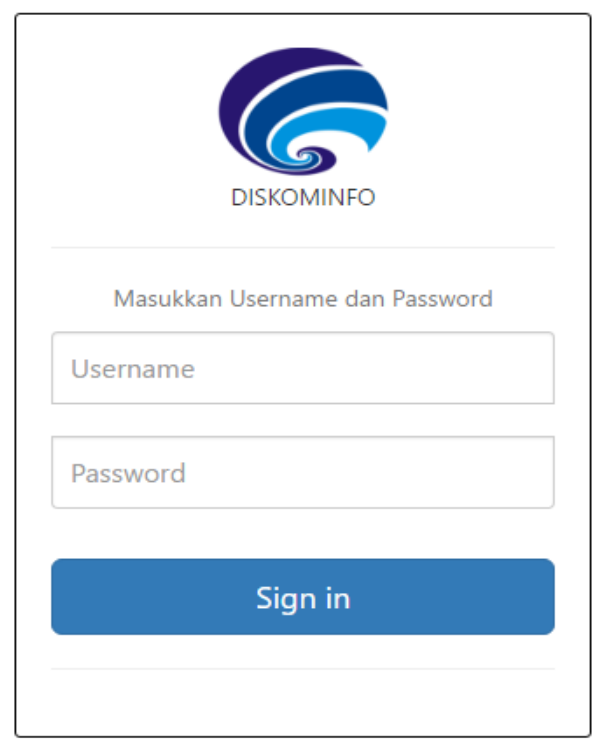

Gambar 5. Antarmuka login Admin, verifikator dan bendahara.

Gambar 5 adalah tampilan untuk login. Admin, verifikator dan bendahara bisa melakukan login dengan memasukkan username dan password pengguna yang telah terdaftar. kemudian klik tombol Sign in, untuk masuk kedalam aplikasi. Sesuai dengan hak akses masing-masing.

\subsubsection{Antarmuka Beranda Admin}

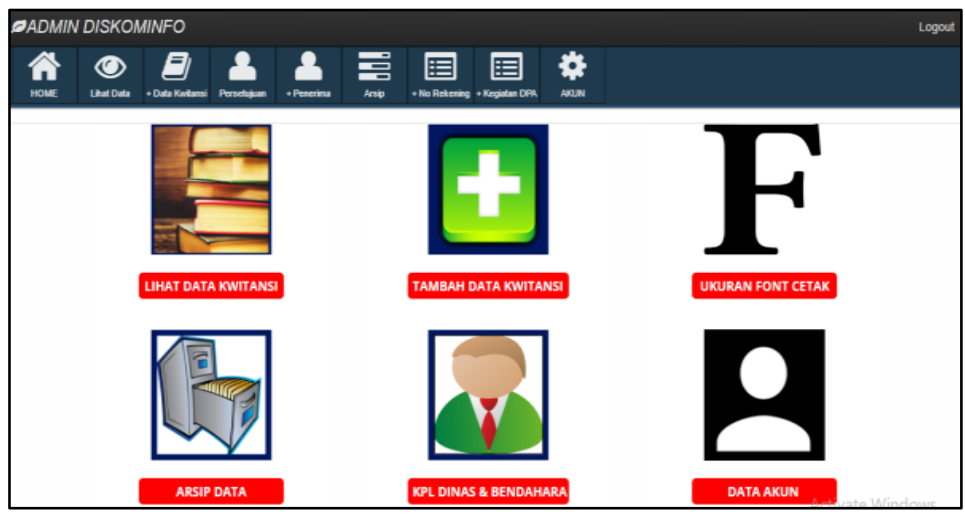

Gambar 6. Antarmuka beranda Admin

Gambar 6 adalah tampilan form halaman utama admin yang mana mempunyai beberapa menu yaitu:

a. Logout adalah menu yang digunakan untuk keluar dari sistem.

b. Home adalah menu yang dituju setelah melakukan login.

c. Tambah data adalah menu untuk menambahkan data.

d. Lihat data adalah menu untuk melihat data yang sudah ditambahkan

e. Tambah penerima adalah menu untuk menambahkan nama Penerima, NIP penerima dan jabatan.

f. Persetujuan adalah menu untuk melihat kepala dinas dan bendahara dinas.

g. Arsip adalah menu arsip data yang sudah ditambahkan.

h. No rekening adalah menu untuk menambahkan no rekening dan juga nama kegiatan.

i. Tambah kegiatan DPA adalah menu untuk menambahkan kegiatan DPA.

j. Akun adalah menu untuk melihat akun pengguna.

k. Ukuran adalah menu untuk mengatur ukuran huruf pada hasil cetak. 


\subsubsection{Antarmuka Lihat Data Kwitansi}

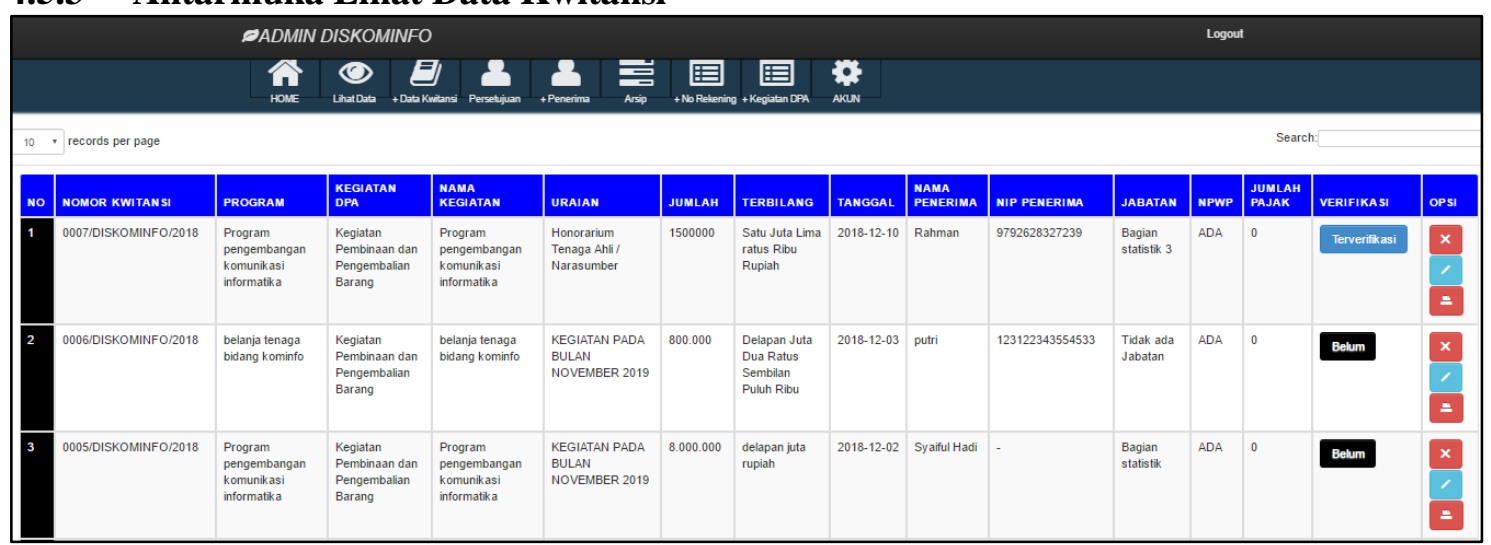

Gambar 7. Antarmuka lihat data kwitansi

Gambar 7 adalah tampilan lihat data kwitansi pada halaman admin dimana pada halaman ini admin bisa melihat data yang terverifikasi dan belum terverifikasi, data no rekening, data kegiatan dan data program.

\subsubsection{Antarmuka Tambah Data Belanja}

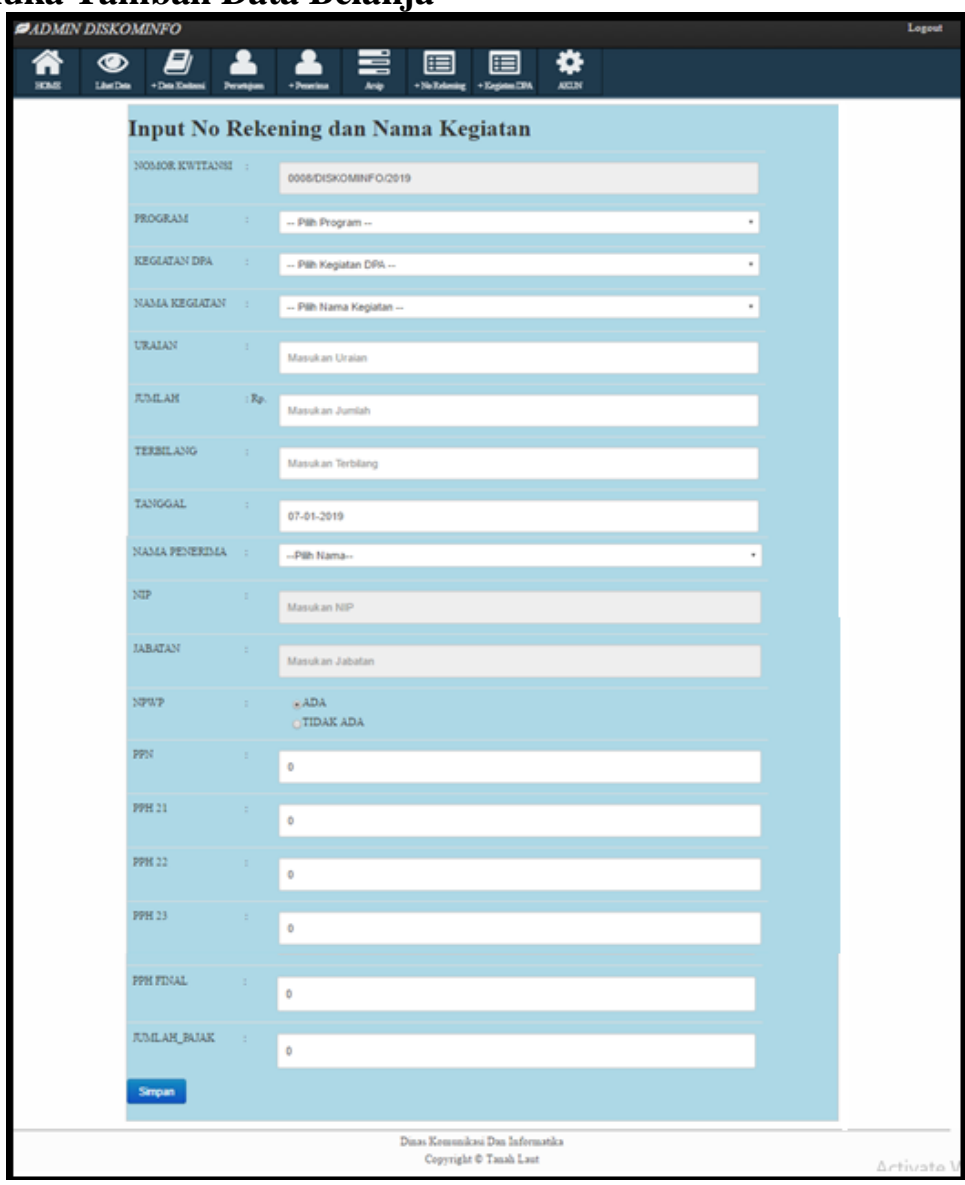

Gambar 8. Antarmuka tambah data belanja

Gambar 8 adalah tampilan form tambah data belanja. Tambah data belanja adalah form yang berfungsi untuk menambahkan. Kemudian tombol Simpan adalah tombol yang berfungsi untuk mengirimkan data yang sudah di input menuju ke database kemudian bisa dilihat pada form lihat data. 


\subsubsection{Antarmuka Tambah No Rekening}

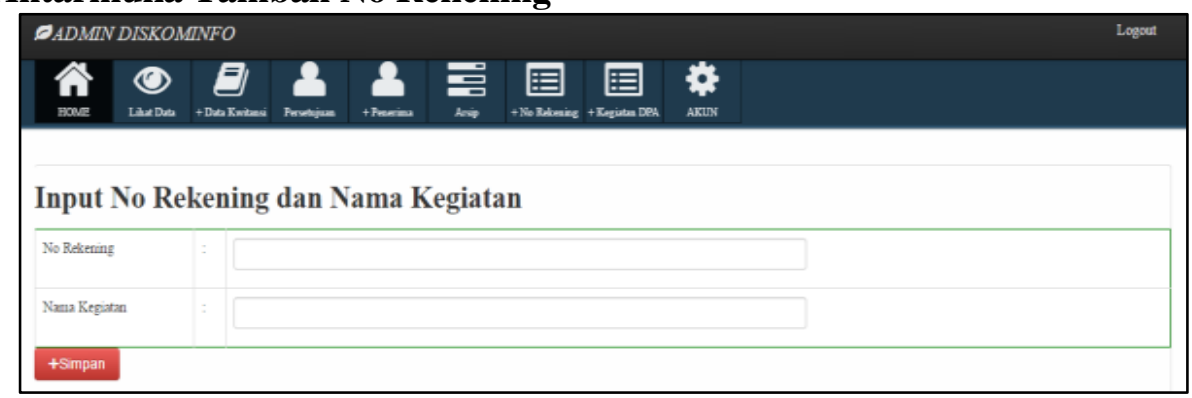

Gambar 9. Antarmuka tambah no rekening

Gambar 9 adalah tampilan form tambah no rekening dimana dalam form ini admin bisa menambahkan no rekening dan menambahkan nama kegiatan.

\subsubsection{Antarmuka Tambah Kegiatan DPA}

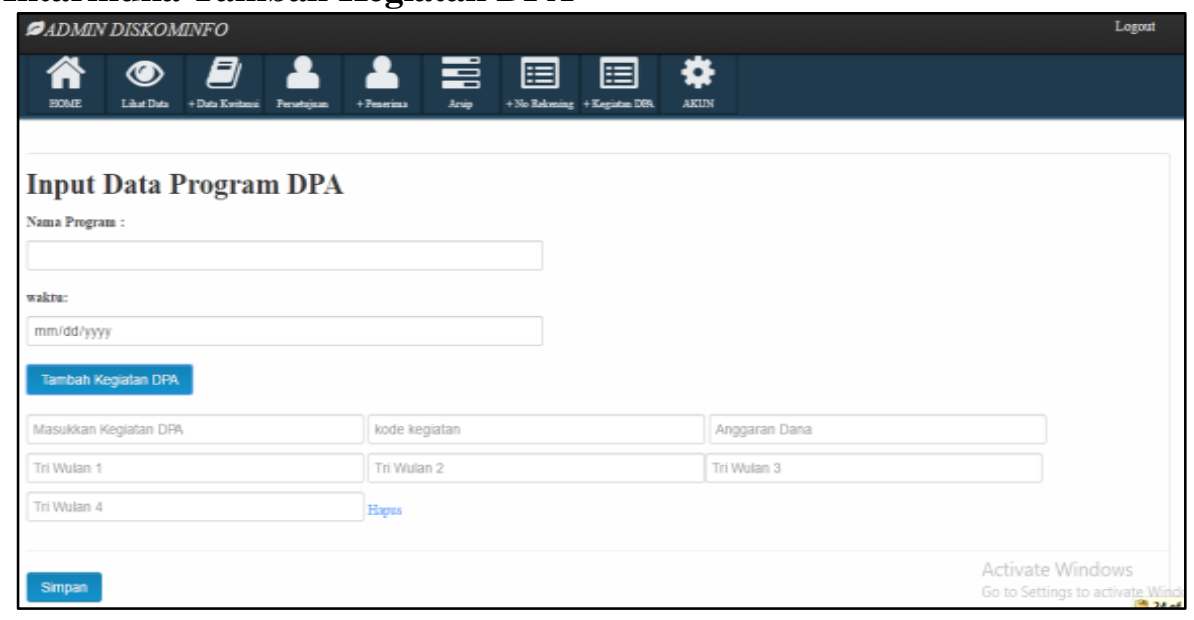

Gambar 10. Antarmuka tambah kegiatan DPA

Gambar 10 adalah rancangan antarmuka form tambah kegiatan DPA. Pada form ini admin bisa menambahkan kode kegiatan DPA dan nama kegiatan DPA.

\subsubsection{Antarmuka Beranda Verifikator}

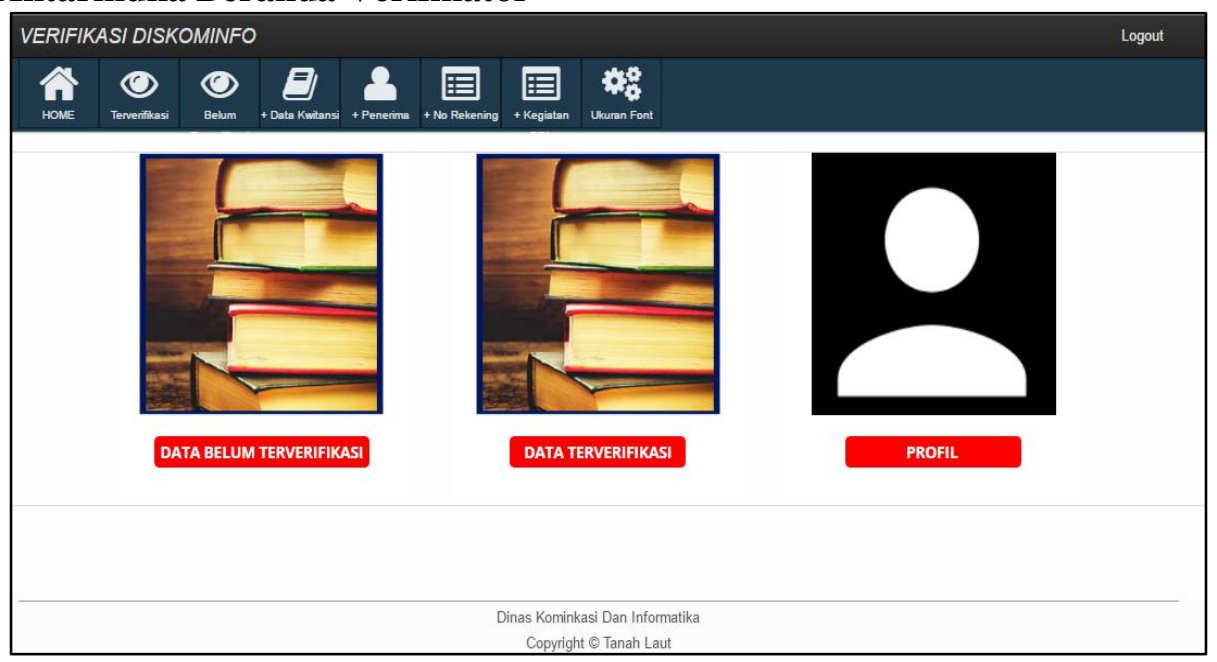

Gambar 11. Antarmuka beranda verifikator 
Gambar 11 adalah tampilan form halaman utama verifikator. Pada halaman ini mempunyai beberapa menu yaitu:

a. Logout adalah menu yang digunakan untuk keluar dari sistem.

b. Home adalah menu yang dituju setelah melakukan login.

c. Tambah data adalah menu untuk menambahkan data.

d. Terverifikasi adalah menu untuk melihat data yang sudah diverifikasi oleh verifikator.

\subsubsection{Antarmuka Data Terverifikasi}

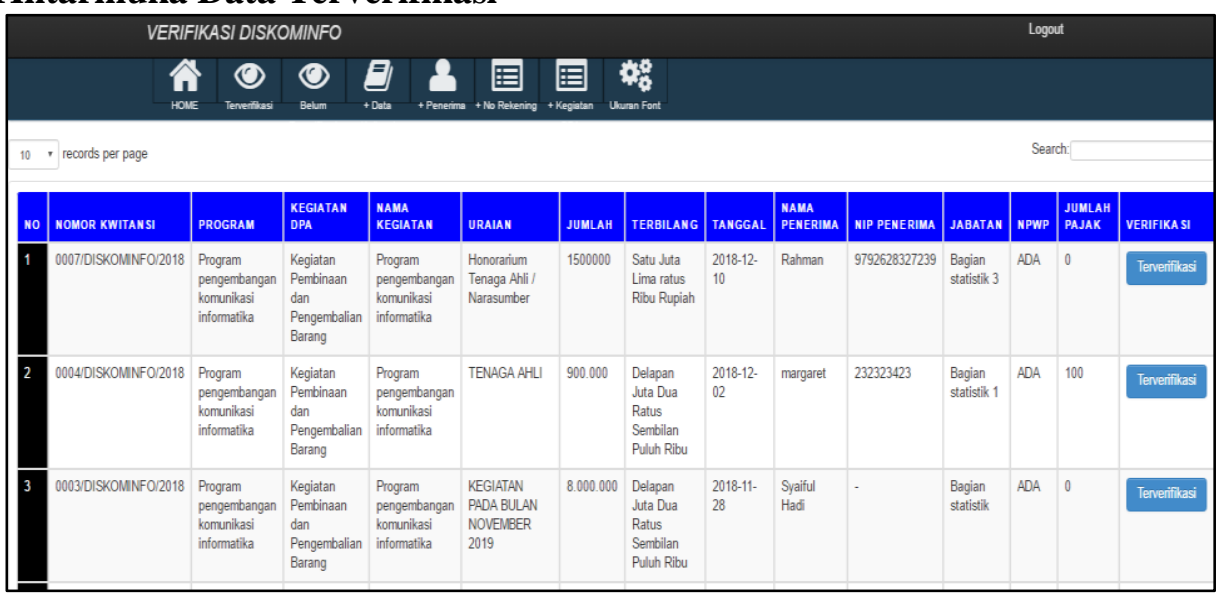

Gambar 12. Antarmuka data terverifikasi

Gambar 12 adalah tampilan form verifikasi. Pada form ini verifikator bisa melihat data yang sudah terverifikasi dan mencetak data terverifikasi tersebut.

\subsubsection{Antarmuka Belum Terverifikasi}

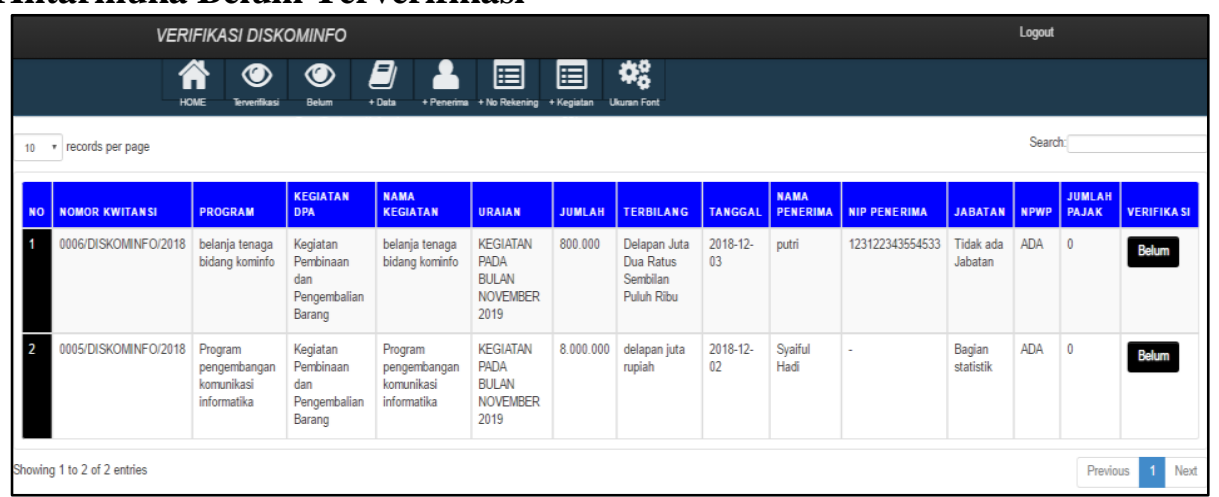

Gambar 13. Antarmuka data belum terverifikasi

Gambar 13 adalah tampilan form verifikasi. Pada form ini verfikator bisa melihat data yang belum terverifikasi.

\section{KESIMPULAN}

Aplikasi manajemen keuangan yang telah dibangun dan sudah terkomputerisasi dapat mempermudah bagian keuangan untuk memanajemen data keuangan secara lebih efektif dan efisien. Dibangunnya sistem ini dapat membantu bagian keuangan dalam pembuatan kwitansi keuangan pada Diskominfo Kabupaten Tanah Laut. Sistem ini dibuat untuk memudahkan dalam pembuatan kwitansi belanja kegiatan DPA, dalam sistem ini juga di sediakan arsip data untuk mempermudah pencarian data yang berjumlah banyak dengan cara yang cepat. 


\section{DAFTAR PUSTAKA}

Isa, I. G. T., \& Hartawan, G. P. (2017). Perancangan Aplikasi Koperasi Simpan pinjam Berbasis Web (Studi Kasus Koperasi Mitra Setia). Jurnal Ilmiah Ilmu Ekonomi (Jurnal Akuntansi, Pajak Dan Manajemen), 5(10), 139-151.

Kadir, A. (2010). Mudah Mempelajari Database. Yogyakarta: Andi.

Kementerian Pendidikan dan Kebudayaan Republik Indonesia. (2016). Aplikasi. In KBBI Daring. Retrieved from https://kbbi.kemdikbud.go.id/entri/aplikasi

Sukamto, R. A., \& Shalahuddin, M. (2016). Rekayasa Perangkat Lunak (Terstruktur dan Berorientasi Objek). Bandung: INFORMATIKA.

Sundjaja, R. S., \& Berlian, I. (2003). Manajemen Keuangan 2, Edisi Keempat. Yogyakarta: Literata Lintas Media.

Syafitri, I. (2019). Pengertian Aplikasi Beserta Fungsi dan Contoh Aplikasi yang Perlu Anda Ketahui. Retrieved January 29, 2019, from https://www.nesabamedia.com/pengertianaplikasi/

Wahana Komputer. (2014). Sistem Informasi Penjualan Online untuk Tugas Akhir. Yogyakarta: Andi.

Winarno, E., Zaki, A., \& SmitDev Community. (2014). 24 Jam Belajar PHP. Jakarta: Elex Media Komputindo.

\section{Biodata Penulis}

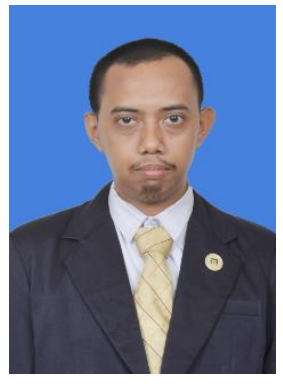

\section{AgustianNoor, M.Kom}

lahir di Banjarmasin, 2 Agustus 1984 menempuh Pendidikan terakhir S2 pada Teknik Informatika Universitas Dian Nuswantoro Semarang Indonesia 2015. Penulis bekerja menjadi Dosen di Jurusan Teknik Informatika Politeknik Negeri Tanah Laut.

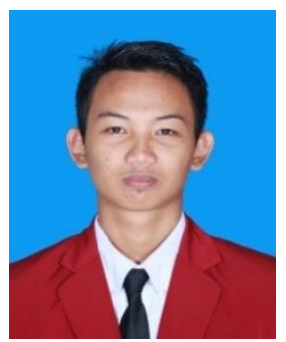

Syaiful Hadi, kelahiran Bati-bati 17 Oktober 1996. Saat jurnal Aplikasi Manajemen Keuangan Berbasis Web Dinas Komunikasi dan Informatika Kabupaten Tanah Laut ditulis, penulis masih menjadi mahasiswa. Penulis mulai berkecimpung pada dunia Teknik Informatika pada tahun 2016 dimana dengan berbekal hobi dan rasa ingin tahu di bidang teknik informatika yang besar terciptalah artikel ini. Penulis sedang giatnya mempelajari SEO (Search Engine Optimation). 